\title{
Adenosine Receptor A2b
}

National Cancer Institute

\section{Source}

National Cancer Institute. Adenosine Receptor A2b. NCI Thesaurus. Code C38614.

Adenosine receptor A2b (332 aa, $\sim 36 \mathrm{kDa}$ ) is encoded by the human ADORA2B gene.

This protein is involved in signaling and cellular defense. 